\title{
Hirschsprung 病無神経節腸管の病態生理に関する研究
}

\author{
兵庫医科大学 第一外科 \\ 岡 空 達夫, 岡 本 英三, 豊 坂 昭 弘 \\ 能 勢 勝 義, 中井謙之, 富 本 喜 文
}

\section{STUDY ON FUNCTION OF AGANGLIONIC COLON MUSCULATURE OF HIRSCHSPRUNG'S DISEASE MURINE MODEL}

Tatsuo Okasora, Eizo Okamoto, Akihiro Toyosaka, Katsuyoshi Nose, Yoshiyuki NakaI and Yoshifumi ToMimoto

First Department of Surgery, Hyogo College of Medicine, Nishinomiya, Hyogo.

\begin{abstract}
This study examined the function in vitro of aganglionic colon musculature in mice with hereditary aganglionosis-a strain of animals used as a model of Hirschsprung's disease. Double sucrose gap recordings from the muscle strips of both normal and aganglionic colon showed bursts of spike potentials with muscle contraction. Intracellular recordings of the membrane potentials of the circular muscle cells of normal, aganglionic and oligoganglionic colon had no statistical difference. Microelectrode recordings from the circular muscle cells of normal siblings, in the presense of nifedipine, irregular ongoing fluctuations in membrance potential, which were abolished by tetrodotoxin and reduced by d-tubocurarine or apamin. The fluctuations were less effected by atropine. These observations suggest that there is ongoing inhibitory neural activity to the circular smooth muscle of normal colon. These ongoing fluctuations were not recorded from the cells of aganglionic and oligoganlionic colon of affected animals. Although transmural stimulation of the intrinsic nerves produced cholinergic excitatory and inhibitory junction potentials in normal colon, no junction potentials were evoked by transmural stimulation in aganglionic colon. It was concluded that the ongoing tonic inhibitory activity may contribute to the compliance of the normal mouse colon and lack of the compliance may affect functional intestinal obstruction of the aganglionic colon in Hirschsprung's disease.
\end{abstract}

\section{緒}

先天的に遠位側結腸の壁内神経を欠き，外来 交感・副交感神経線維の增生を認める Hirschsprung 病の無神経節腸管に捛いて, その平滑筋 が神経支配の無い状態にあることは既に報告し た（岡空ら，1983; Okasora \& Okamoto, 1986). 今回, Hirschsprung 病の病態生理を把
言

握する目的で，この神経支配の無い無神経節腸 管の平滑筋が如何なる状態にあるかを検討し た。すなわち, Hirschsprung 病モデルマウスの 摘出腸管を材料にして，二重庶糖隔絶法ならび に微小電極法を用いた電気生理学的研究を行っ た。

\section{II. 研究対象ならびに研究方法}


ら，1979） piebald lethal マウス（s1/s1）20匹 を研究対象とし，正常対照には正常な腸管を有 する同胞 $(\mathrm{s} 1 /$ + または十/+)20匹を用いた。、 ウス (雌雄同数, 15 20 g) 頭部を強打して失 神させた後, 頝動脈を切断して失血死せしめた。 直ちに開腹して肚門を含む遠位側結腸を摘出 し，修正 Krebs 液内で以下の操作を行い標本を 作成した。すなわち，二重庶糖隔絶法に供する 標本は粘膜を注意深く剝離したのち縦切し, 大 きさ約 $1.5 \times 20 \mathrm{~mm}$ の 2 条の筋条片とした．次 いで，中央には修正 Krebs 液を潅流し，その両 外側に $1 \mathrm{M}$ 庶糖液, さらに外側は $3 \mathrm{M} \mathrm{KCl}$ を 貯留した装置に装着した（Ito et al., 1977）。ま た，微小電極を用いた細胞内電位測定法では最 遠位側結腸の全層標本を約 $5.0 \times 30 \mathrm{~mm}$ の大き さにトリミングし，漿膜を上方にして修正 Krebs 液 $\left(37^{\circ} \mathrm{C}\right)$ を潅流した $(2.5 \mathrm{ml} / \mathrm{min})$ organ

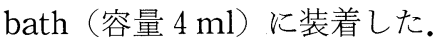

二重庶糖隔絶法では無神経節腸管および正常 腸管の平滑筋の自発膜活動を細胞外に導出記録 し，同時に筋張力を等尺性に記録した（Ito et al., 1977). 微小電極法はガラス毛細管を微小電

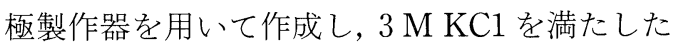
微小ガラス電極（40 80 M $\Omega$ )を用いて行った. すなわち，上記の如くに装着した標本で，漿膜 抒よび縦走筋細胞を通過して輪状筋細胞に刺入 し，膜電位を記録した。また，標本の上下に装 着した 1 対の白金電極を通して経壁刺激を行 い, その結果として生ずる膜電位変化（接合部 電位)を記録した（Okasora，Bywater \& Taylor, 1986).

\section{III. 研 究}

\section{1）自発膜活動}

二重庶糖隔絶法で平滑筋細胞の静止時の自発 膜活動を記録すると，約半数の標本で図 1 に示 すような膜活動が記録された。すなわち頻度が $0.3 \sim 1.5 \mathrm{cpm}$ で 2 15 個ずつ集蔟する spike 電 位 (2〜 7 mV)が記録された。そしてそれらには すべて筋の収縮を伴って扔り, 電位が $1 \sim 5 \mathrm{mV}$ の slow waveが認められる場合には slow wave に重畳していた。
二重庶糖隔絶法および微小電極法の電位記録 には日本光電工業社製の平衡型微小電極用増幅 器 MEZ-7101, 前置増幅器 AVH-9 抢よび万能 2-4 現象オシロスコープを用いた。張力記録に は FD ピックアップ TB-612T 拉よびひずみ圧 力用アンプ AD-620Gを用いた。いずれもいっ たんテアック社製カセットデータレコーダー MR-10 に記録してデータ分析に供し, 永久記録 には日本光電工業社製レクチコーダーを用い た。経壁刺激には日本光電工業社製電気刺激装 置 SEN-7103 招よびアイソレーターSS-102J を用いて， $50 \sim 70 \mathrm{~V}, 0.5 \mathrm{sec}, 20 \mathrm{~Hz}$ の直流矩形 波を用いた。な扔，二重庶糖隔絶法に抢ける電 位導出には銀／塩化銀電極を用い, 微小電極法 では白金電極を用いた。

本研究に用いた修正 Krebs 液は, 組成として $\mathrm{NaCl} 120 \mathrm{mM}, \mathrm{KCl} 5.0 \mathrm{mM}, \mathrm{CaCl}_{2} 2.5 \mathrm{mM}$, $\mathrm{MgCl}_{2} 1 \mathrm{mM}, \mathrm{NaH}_{2} \mathrm{PO}_{4} 1 \mathrm{mM}, \mathrm{NaHCO}_{3} 25$ $\mathrm{mM}$, glucose $11 \mathrm{mM}$ を含み, $95 \% \mathrm{O}_{2}-5 \% \mathrm{CO}_{2}$ 混合気体を送気して $37^{\circ} \mathrm{C}$ に調整したものを用 いた。微小電極法を用いた実験では標本の動き を抑制する目的で, 潅流液中にニフェヂピン (Sigma)を添加した。薬理学的検討に供した薬 剤すなわち硫酸アトロピン(田辺製薬), テトロ ドトキシン(Sigma), アパミン(Sigma), 塩酸 ツボクラリン(和光純薬)は全て用時調整し, 潅 流せる修正 Krebs 液内に添加した。微小電極法 で記録された輪状筋の静止時膜電位はすべて平 均土平均標準偏差(記録細胞数)で表現した。ま た，統計的分析はStudent の $\mathrm{t}$ 検定を用いて 行った.

\section{成 績}

この自発膜活動は正常対照の標本でも（図 $2 \mathrm{~A})$ ，無神経節腸管の標本でも（図 2B）記録さ れ，アトロピン $(0.7 \mu \mathrm{M})$ あるいはテトロドト キシン $(0.7 \mu \mathrm{M})$ を加光ても, 電位の大きさ抒 よび発生頻度に变化を生じなかった。

\section{2）静止時膜電位}

ガラス電極が良好に正常対照の輪状筋細胞に 刺入された場合，本研究ではニフェヂピン $(0.2$ $\mu \mathrm{M}$ ）を潅流して自発膜活動を抑制しているの 


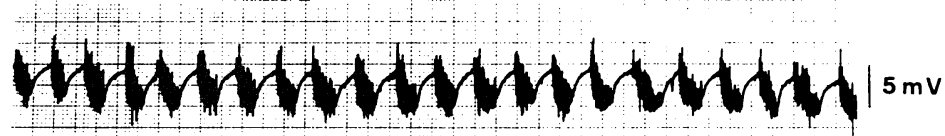

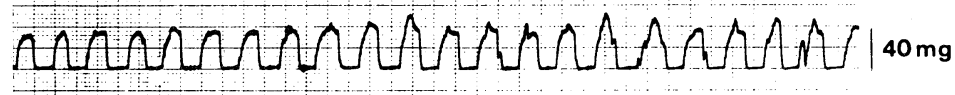 \\ $\overline{\mathrm{min}}$}

図 1. 二重庶糖隔絶法で記録された正常結腸筋条片の自発膜活動の典型例. 上に膜電位，下に筇張力を 示す。

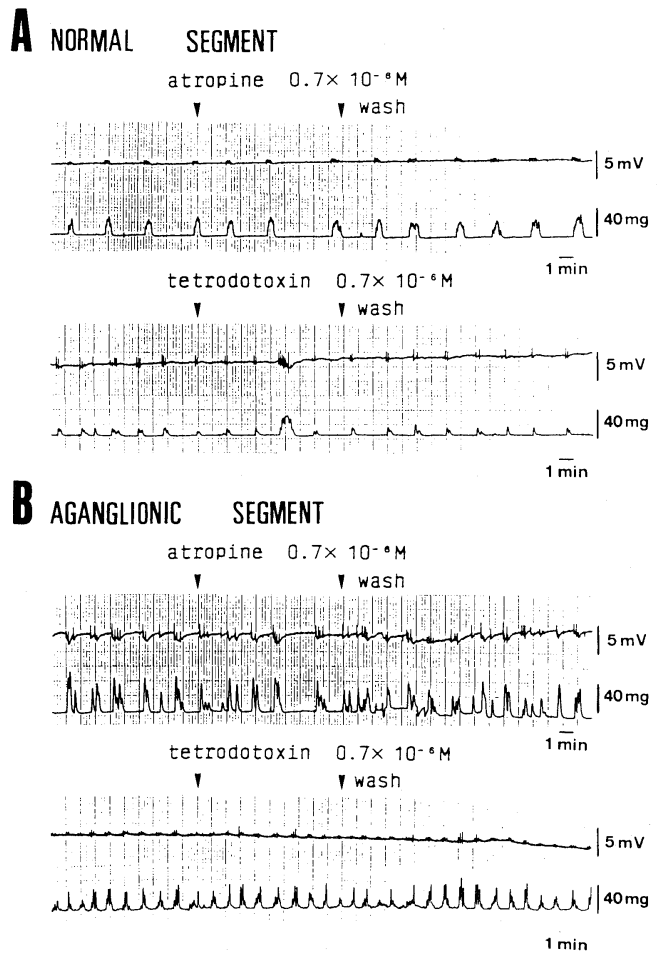

図 2. 二重庶糖隔絶法で記録された自発膜活動に 対する薬物の効果. A は正常腸管, B は無神 経節腸管での記録を示す。それぞれ上に膜電 位，下に筋張力を示す。

で上記の slow waveあるいは spike 電位様の 電位変化は記録されないにもかかわらず，大半 の細胞の膜電位は安定しておらず, $10 \mathrm{mV}$ に満 たない微小で持続性の不規則な波動様の電位変 化が記録された。この電位変化は脱分極側にも 過分極側にも認められ，アトロピン $(1.4 \mu \mathrm{M})$ 投 与で活とんど変化が生じず，テトロドトキシン

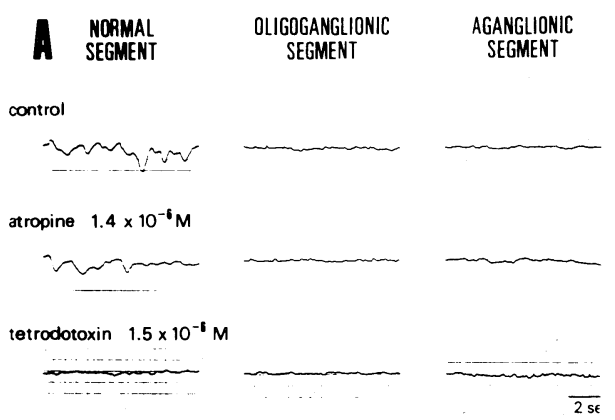

atropine $1.4 \times 10^{-6} \mathrm{M}$

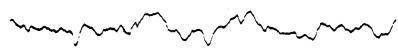

dtc $10^{-4} \mathrm{M}$

apamin $5 \times 10^{-7} \mathrm{M}$

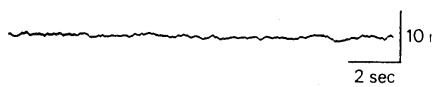

図 3. 微小電極法で記録された波動様電位変化と 薬物の効果. A では正常腸管, 移行部腸管, 無 神経節腸管で記録された波動様電位変化と それに対するアトロピンおよびテトロドト キシンの効果を示す. B では正常腸管で記録 された波動様電位変化に対するッボクラリ ンおよびアパミンの効果を示す.

（1.5 $\mu \mathrm{M}$ ) 投与によりほとんど消失した（図 3A). 一方, 無神経節腸管抒よび移行部腸管にお いてはガラス電極が輪状筋に刺入されてもこの ような不規則な波動梯電変化は記録されなかっ た（図 3A).

また正常対照でえられた波動様電位変化は二 コチン性抗コリン剤であるッボクラリン（100 


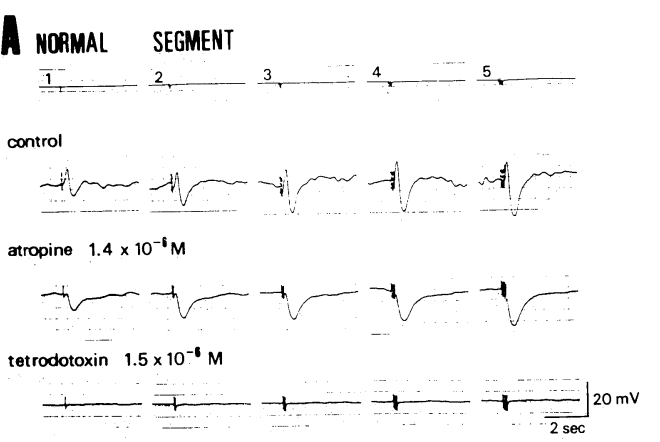

3 OLIGOGAMGLIONIC SEGMENT

control

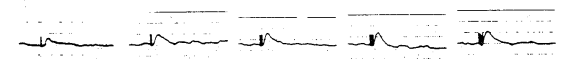

atropine $1.4 \times 10^{-6} \mathrm{M}$

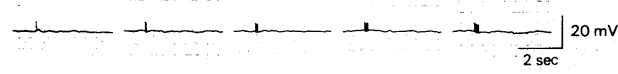

\section{agANGLIONIC SEgMENT}

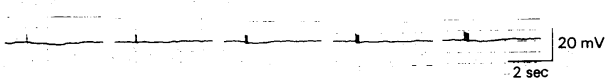

図 4. 微小電極法に打いて経壁刺激により得られ た接合部電位と薬物の効果. A は正常腸管, $\mathrm{B}$ は移行部腸管，Cは無神経節腸管における 記録を示す。最上段は経壁刺激を与光た位置 および train 数を示す。

$\mu \mathrm{M})$ の投与によりかなりの電位減少を認め，同 様に非コリン性非アドレナリン性抑制神経によ る抑制性接合部電位を減少せしめるハチ毒のア パミン $(0.5 \mu \mathrm{M})$ 投与で減少を認めた（図 $3 \mathrm{~B})$.

したがって，微小電極法で測定した正常対照 の輪状筋の静止時膜電位の測定は, 波動様電位 変化の活济中央をとった。無神経節腸管预よび

\section{IV. 考}

Hirschsprung 病の無神経節腸管に掞いては 壁内神経細胞を先天的に欠如するだけではな く, 外来の交感・副交感神経線維はむしろ増生 していることは周知の事実である。その増生し た外来神経が無神経節腸管の平滑筋に対して支 配を及ぼしているか否かに関し，従来より我々 は神経支配をして抢らず，同部の平滑筋は全く 神経支配を受けていない状態にあると主張して 来た。事実, 我々のグループの研究では, 形態
移行部腸管の静止膜電位の測定は, 両部に波動 様膜電位変化がないので容易であった。このよ らにして記録した静止時膜電位は正常対照がー $50.0 \pm 0.9 \mathrm{mV}(\mathrm{n}=62)$ であった. 一方, 無神経 節腸管ではー $48.1 \pm 0.9 \mathrm{mV}(\mathrm{n}=30)$ であり, 両 者の中間の移行部腸管ではー $49.2 \pm 1.2 \mathrm{mV}$ ( $\mathrm{n}=38)$ であった. 3 者の間には統計的な有意差 は認めなかった。

\section{3）経壁刺激により得られた接合部電位}

正常対照腸管の上下に装着した一対の刺激電 極より経壁刺激を加兄ると, 輪状筋細胞では脱 分極と過分極の二相性の電位変化が記録され た。両電位とも刺激の回数を増加するとその大 きさも増加した。そしてアトロピン $(1.4 \mu \mathrm{M})$ 投 与により脱分極は消失し，過分極が大きくなっ た。そしてテトロドトキシン $(1.5 \mu \mathrm{M})$ 投与に より両電位とも消失した(図 $4 \mathrm{~A}$ )。したがって, 脱分極側の変化はコリン作動性興奮神経による 興奮性接合部電位であり, 過分極側の変化は非 コリン非アドレナリン作動性抑制神経による抑 制性接合部電位々考光られる。

無神経節腸管に経壁刺激を与えても, 同部の 輪状筋細胞には如何なる応答も記録されなかっ た（図 4C).

また両者の中間の移行部腸管に経壁刺激を加 えた際には，一部の標本で $(2 / 10)$ 微小な興奮 性接合部電位が得られた（図 4B)。この興奮性 接合部電位もアトロピン $(1.4 \mu \mathrm{M})$ 投与により 消失したが，抑制性接合部電位は記録されな かった。

\section{察}

学的なアプローチを用いた研究(岡本, 1983)で も, 生理学的・薬理学的手法を用いた研究（岡 空ら, 1983 ; Okasora \& Okamoto, 1986 ; Ueki et al., 1985）でも，その考觉を支持する結果を 得ている。しかし一方では, この主張に対して 異論があることも事実である。本研究は電気生 理学的・薬理学的に再度我々の主張を裏付けん として施行したものである.さらに同様な手技 を用いて，無神経節腸管の平滑筋が如何なる病 
態にあり，どのような機序で本症の通過障害が もたらされたかを検討した。

経壁刺激に対する応答に関しては前報（岡空 ら 1983 ; Okasora \& Okamoto, 1986) と同様 に正常対照に和いては，アトロピンで消失する 興奮性接合部電位とそれに引続く抑制接合部電 位が記録された。すなわち，正常結腸では主に， コリン作動性興奮神経と非コリン非アドレナリ ン作動性抑制神経の支配が存在する。一方, 無 神経節腸管に打いては如何なる接合部電位も記 録されず，同部は神経支配の無い状態にあると いわざるを得ない。本研究ではさらに壁内神経 の乏しい部分である移行部腸管に招ける経壁刺 激の応答を記録した。極く一部の標本に扔いて 微小な興奮性接合部電位が記録された。ただし， 後に言及するが，この事実から同部にコリン作 動性興奮神経の支配があり, 通過障害の主因で あるとは断定し難く，この接合部電位の意義に 関してはさらに検討が必要と考える。

二重庶糖隔絶法を用いた実験で無神経節腸管 に扮いても, 正常対照に扔いても同様の自発膜 活動が得られ，神経の活動を遮断するテトロド トキシンを投与しても変化を生じなかった。ささ らに微小電極法で得られた静止時膜電位に差が 無かったことと併せて, 両部の平滑筋細胞自体 には差が無いことを示唆している。ところが, カ ルシウム拮抗剤であるニフェヂピンの投与下 で，自発膜活動を抑制したところ，正常対照の 標本にのみ, 静止時に持続性の不規則な波動様 の電位変化が記録された（Okasora, Bywater \& Taylor, 1986). この持続性波動様電位変化は アトロピンでやや抑制され，テトロドトキシン で泳ぼ消失した。ささにニコチン作動性シナッ プスの遮断剂であるッボクラリン，あるいは非 コリン非アドレナリン作動性抑制神経による抑 制性接合部電位を抑制するハチ毒アパミンによ りかなりの電位低下を認めた。この事実は正常 腸管の平滑筋に括いては, コリン作動性興奮神

\section{V. 結}

Hirschsprung 病の無神経節腸管の平滑筋が 如何なる病態にあるかを明らかにする目的で,
経㧍よび非コリン非アドレナリン作動性抑制神 経の持続性の活動があり, 特に非コリン非アド レナリン作動性抑制神経の持続性活動が活発に 行なわれていることを示唆している。すなわち， この抑制神経の持続性活動が正常腸管のコンプ ライアンスを形成していると考光られる。この ことはモルモットの結腸を使用した研究（Furness et al., 1977 ; Davidson et al., 1979) 飞未 いて, 結腸拡張刺激の後, 反射的な抑制運動神 経の緊張性活動により腸管コンプライアンスの 上昇がみられ，乙かもテトロドトキシンはそれ を抑制したといら報告からも支持される。さら に，Wood (1981)による腸管のトーニックな収 縮あるいは拡張不全は内在性の抑制性運動神経 の欠如に起因するといら報告からも支持され る。したがって，無神経節腸管抒よび移行部腸 管に打いては抑制性運動神経の欠如に基づく腸 管コンプライアンスの低下が存在することは明 らかで，これが本症の機能的腸閉塞症状をもた らす主因であろうと考兄られる。この結果は無 神経節腸管では経壁刺激に対する応答が全く得 られなかったといら事実（同部には神経支配が 無いといら結果) と矛盾が無い。一方，無神経 節腸管にはコリン作動性興奮神経の支配がある と主張する研究者の中には, 同神経の持続的支 配が無神経節腸管の狭小化をもたらしていると 考えがある、本研究では, 無神経節腸管あるい は移行部腸管に和いて, 興奮性運動神経が持続 的に活動しているという証左は得られていな い.すなわち，興奮神経の持続的活動が存在す るとすれば, 静止時膜電位の上昇, あるいはア トロピンで消失する持続性波動様電位変化が記 録されてしかるべきであろう。前記の移行部腸 管に抢ける興奮性接合部電位の存在について は，静止時には興奮神経の活動による変化がな んら記録されていないことから，一元的な説明 が得られず，今後の検討を待ちたい。

\section{語}

モデルマウスの摘出腸管を用いて電気生理学的 検討を加え, 以下の結論を得た。 
1）平滑筋自体の性質に関しては，正常対象 と無神経節腸管の間に差は無いものと考学られ た。

2）正常対象の平滑筋では, 非コリン非アド レナリン作動性抑制神経の持続的な活動を示唆 する所見が得られたが，移行部ならびに無神経 節腸管の平滑筋では認められなかった。この活 動が正常腸管のコンプライアンスを形成してい るものと考光られ，逆に無神経節腸管に括いて

\section{文}

はこの活動の欠如が機能的腸閉塞の主因であろ らと考えられた。

3）正常腸管の平滑筋はコリン作動性興奮神 経掞よび非コリン非アドレナリン作動性抑制神 経の支配があるものと考学られた。一方無神経 節腸管の平滑筋はこれらの神経支配の存在を示 唆する所見は得られず，同部は神経支配の無い 状態にあるものと考光られた。

Davidson, J.S. \& Pearson, G.T. (1979). The role of intrinsic, non-cholinergic, non-adrenergic inhibitory nerves in the regulation of distensibility of the guinea-pig colon. Pflïgers Arch. 381 : 75-77.

Furness J.B. \& Costa, M. (1977). The participation of enteric inhibitory nerves in accommodation of the intestine to distension. Clin. Exp. Pharmacol. Physiol. $4: 34-71$.

Ito, Y., Suzuki, H. \& Kuriyama, H. (1977). Effects of caffeine and procaine on the membrane and mechanical properties of the smooth muscle cells of the rabbit main pulmonary artery. Jap. J. Physiol. 27 : 521-537.

岡本英三 (1983)。無神経節晹管の病態生理. 日本平滑筋学会雑誌 19:397-414.

岡空達夫, 岡本英三, 桑田圭司, 豊坂昭弘, 大橋秀一, 植木重文 (1983). Hirschsprung 病無神経節腸管の 神経支配に関する研究。日本小児外科学会雑誌 19：491-497.

Okasora, T., Bywater, R.A.R. \& Taylor, G.S. (1986). Projections of enteric motor neurons in the mouse distal colon. Gastroenterology $90: 1964-71$.

Okasora, T. \& Okamoto, E. (1986). Electrophysiological and pharmacological study on innervation of the aganglionic colon in Hirschsprung's disease of human and murine model. Z. Kinder. chir. 41 : 93-96.

植木重文, 岡本英三 (1979)。 川俣順一, 松下宏 (編), 疾患モデル動物ハンドブック, 292-296 頁, 医歯薬 出版, 東京.

Ueki, S., Okamoto, E., Kuwata, K., Toyosaka, A. \& Nagai, K. (1985). Qualitative and quantitative analysis of muscarinic acetylcholine receptors in the piebald lethal mouse model of Hirschsprung's desease. Gastroenterology $88: 1834-41$.

Wood, J.D. (1981). Physiology of enteric nervous system. in Johnson, L.R. (editor) Physiology of the gastrointestinal tract. pp. 1-37, Raven, New York. 